\title{
Prenatal Development of Pelvic Urethra in Goat (Capra hircus)
}

\author{
Desarrollo Prenatal de la Uretra Pélvica en Cabras (Capra hircus)
}

\author{
Abhinov Vrema; Archana, P.; M. M. Farooqui \& Ajay Prakash
}

VREMA, A.; ARCHANA, A.; FAROOQUI, M. M. \& PRAKASH, A. Prenatal development of pelvic urethra in goat (Capra hircus). Int. J. Morphol., 31(2):729-738, 2013.

SUMMARY: The study was conducted on the embryo/foeti of goat from 0-150 days of gestation, divided into group I (0-30 days), group II (31-60 days), group III (61-90 days), group IV (91-120 days) and group V (121-150 days of gestation). In group I whole embryo was processed and serial sections were cut whereas, in rest of the groups, pelvic urethra was dissected out and the tissues from the representative areas were used for the study. Grossly, on 49.33 days of gestation the pelvic urethra was present in the form of smooth cylindrical tube, approximately $4 \mathrm{~mm}$ in length. The primordial of vesicular gland and bulbourethral gland appeared on 52 days of gestation at the junction of neck of urinary bladder with pelvic urethra and at the junction of pelvic and penile urethra respectively. The length, width, height and circumference of pelvic urethra increased with increased in gestation period, however the length ( 7 times) and circumference ( 9 times) increased maximum from group II to group V. The morphometrical parameters (length, width, height and circumference) of pelvic urethra were significantly correlated with the age and weight of foetus throughout gestation period. The colliculus seminalis, which was present in the form of ridge on 72 days of gestation, became distinct on 75 days of gestation. Histologically, on 28 days of gestation, the urogenital sinus was present as a cleft with in the cluster of cells. On 55 days of gestation, the process of luminization started with in the wall of pelvic urethra, which started first in its caudal part and proceeded cranially. All the four layers (Tunica mucosa, submucosa, muscularis and adventitia) were distinct. The lumen was lined with 3-4 layers of stratified epitheliumin group II but in group III on 70 days of gestation and beyond this distinct transitional epithelium was present. The formation of cavernous spaces started at 59 days of gestation. Their number and size increased with increased in gestation period. The thickness of submucosa, muscularis and adventitia increased with the advancement in the age of foetus, whereas the height of epithelium decreased.

KEY WORDS: Anatomy; Histology; Pelvic urethra; Goat.

\section{INTRODUCTION}

Pelvic urethra is a complex muscular tube, which extends from urinary bladder to the ischial arch and it is a common passage for both urinary and reproductive system. All the three accessory sex glands pour their secretions in to the urethra where at the time of ejaculation they are mixed with the suspension of spermatozoa and ampullary secretion from the ductus deferens. On perusal of literature it has been observed that little attention has been paid towards the development of pelvic urethra. However the documentation of normal embryonic and foetal developmentis necessary to understand the consequences of harmful influences at various stages of gestation (Evans \& Sack, 1973). Hence an effort has been made to study the development of pelvic urethra in prenatal goat.

\section{MATERIAL AND METHOD}

The present study was conducted on the pelvic urethra of 30 embryos/foeti of goat (capra hircus) from 0-150 days of gestation. The approximate age of foeti were estimated by using the formula derived by Singh et al. (1979) in goat. The foeti were divided into five groups consisted of 6 animals in each viz.; Group I (0-30 days), Group II (31-60 days), Group III (61-90 days), Group IV (91-120 days) and Group V (121-150 days) of gestation. The pelvic urethra was dissected out and after taking all gross morphometrical parameters it was fixed in $10 \%$ neutral buffered formaline. The fixed tissues were processed through routine alcohol-benzene schedule, infiltrated and embedded in paraffin $\left(60-62^{\circ} \mathrm{C}\right.$ melting point). The cold acetone fixed tissues were embedded in paraffin of low melting point $\left(52-54^{\circ} \mathrm{C}\right)$ for carbohydrate 
and enzyme study. Thin paraffin sections $(5 \mu)$ were cut and stained with Haematoxylin and Eosin for routine fibrocellular architecture, Van Gieson's stain for collagen, Wilder's reticular stain (for reticular fibers and Verhoeff's stain for elastic fibers, PAS with and without saliva as well as diastase for polysaccherides and glycogen, Muller's colloidal (hydrous) ferric oxide (Luna, 1968) for acid mucopolysaccherides (AMPS), Gomori's method for alkaline and acid phosphatase (Davenport, 1960), Sudan Black-B (Bancroft \& Stevens, 1977) for lipids and Feulgen's reaction for DNA demonstration (Davenport). Micrometrical measurements were recorded with the help of calibrated ocular micrometer. Data were subjected to standard statistical analysis (Snedecor \& Cochran, 1967) with the help of SPSS 17.0 software for interpretation.

\section{RESULTS AND DISCUSSION}

Gross Anatomy. In group II, at 49.33 days of gestation, the pelvic urethra in prenatal goat was cylindrical in shape and smooth in appearance. Its lumen was very narrow. It was tightly attached with rectum dorsally. Farooqui (2004) also described that the pelvic urethra and rectum developed as separate structure at 50th day of gestation in prenatal goat. The length of pelvic urethra from neck of urinary bladder up to root of penis was $4 \mathrm{~mm}$. On 52 days of gestation, the length of pelvic urethra was $4.5 \mathrm{~mm}$. The primordium of vesicular gland was formed as an elongated enlargement on the dorsal surface, at the junction of neck of urinary bladder with pelvic urethra. It was reaching up to half of the total length of pelvic urethra. At the same time, two small rounded swellings i.e. the primordia of bulbourethral glands were seen at the junction of pelvic urethra and penile urethra. The two distinct vas deferens entered into the dorsal wall of pelvic urethra on 55 days of gestation (Fig. 1). With the increased in gestation period the length of pelvic urethra increased. On 59 days of gestation, the length of pelvic urethra became $6 \mathrm{~mm}$. A very strong kink was present at the junction of pelvic and penile urethra. Here the bulbourethral glands were present which became larger in size than the previous age. The overall average length, height, width and circumference of pelvic urethra in group II were $4.60 \pm 0.38,1.45 \pm 0.15$, $1.43 \pm 0.14$ and $2.82 \pm 0.30 \mathrm{mms}$, respectively (Table I).

In group II, the age of foetus was highly significantly correlated with length (0.966), height (0.963), width (0.978) and circumference (0.945) of pelvic urethra and vice versa. Similarly the weight of foetus was also significantly correlated with the above said parameters (Table II). The length of pelvic urethra was highly significantly correlated with height $(0.980)$, width (0.975) and circumference (0.975) and vice versa. Thus the data indicated that with the increased in age, all the parameters of pelvic urethra increased simultaneously.

In group III, on 70 days of gestation, the lumen of pelvic urethra was distinct, into which ducts of vas deferens, pars disseminata of prostate gland, vesicular glands and bulbourethral glands opened. On 72 days of gestation, a longitudinal ridge like structure was present in cranial $1 /$ 3rd part of pelvic urethra internally which became distinct as colliculus seminalis on 75 days of gestation (Fig. 2). It was in the form of central raised eminence, continued caudally with the longitudinal ridge. The size of pelvic urethra increased with the increased in gestation period and on 81 days of gestation its length became $11 \mathrm{~mm}$. In group III the overall average length, Width and circumference was $10.22 \pm 0.44,2.79 \pm 0.11,2.77 \pm 0.09$ and $7.70 \pm 0.55 \mathrm{mms}$, respectively (Table I).

In group III, all biometrical parameters of pelvic urethra increased significantly from group II (Table I). The length increased from $4.60 \mathrm{~mm}$ to $10.22 \mathrm{~mm}$ and the circumference increased more than 3 times from the group II in group III. The biometrical parameters were highly significantly correlated with age and weight of foetus at $1 \%$ level of significance (Table II). The length of pelvic urethra was highly significantly correlated with height (0.979), width (0.984) and circumference (0.967) and vice versa. The circumference of pelvic urethra was highly significantly correlated with length and width at $1 \%$ level of significance but correlated with height at $5 \%$ level of significance.

In group IV, on 93 days of gestation, pelvic urethra showed fat deposition in the cranial part around the vesicular glands (Fig. 3). Fat deposition increased with increase in age. On dissecting pelvic urethra at 98 days of gestation, its wall showed whitish spots that would be the openings of prostate gland, which were arranged in rows in the internal wall of pelvic urethra. The wall of pelvic urethra became more muscular on 116 days of gestation. On dissection, it showed longitudinal ridges which were 3-4 in number. The ridge which forms the collicullus seminalis was prominent and extended beyond the proximal extremity of the collicullus seminalis up to the neck of urinary bladder. Farooqui observed a distinguishable collicullus seminalis at 125 days of gestation.

In group IV the overall mean length, height, width and circumference were $17.98 \pm 1.0,3.55 \pm 0.12,3.48+0.08$ and $11.67 \pm 0.80 \mathrm{~mm}$, respectively (Table I). In group IV the length, height, width and circumference were highly significantly correlated with age and weight of foetus at $1 \%$ level of significance (Table II). The length of pelvic urethra 
Table I. Morphological Parameters (Mean \pm S.E.) of pelvic urethra in prenatal goat in various gestation period.

\begin{tabular}{llcccc}
\hline S. N. & Parameter $(\mathrm{mm})$ & Group-II & Group - III & Group - IV & Group $-\mathrm{V}$ \\
& & Mean \pm S.E. & Mean \pm S.E. & Mean \pm S.E. & Mean \pm S.E. \\
1. & Length & $4.60^{\mathrm{a}} \pm 0.38$ & $10.22 \mathrm{~b}+0.44$ & $17.98 \mathrm{c}+1.00$ & $27.20^{\mathrm{d}}+1.40$ \\
& & $(3.3-6)$ & $(9-11.8)$ & $(16-22)$ & $(23.20-32.00)$ \\
2. & Height & $1.45^{\mathrm{a}}+0.15$ & $2.79^{\mathrm{b}}+0.11$ & $3.55 \mathrm{c}+0.12$ & $4.43^{\mathrm{d}}+0.16$ \\
& & $(1-2)$ & $(2.5-3.2)$ & $(3.3-4)$ & $(4.00-5.00)$ \\
3. & Width & $1.43^{\mathrm{a}}+0.14$ & $2.77^{\mathrm{b}}+0.09$ & $3.48 \mathrm{c}+0.08$ & $4.42^{\mathrm{d}}+0.17$ \\
& & $(1-1.9)$ & $(2.5-3.1)$ & $(3.3-3.8)$ & $(4.00-5)$ \\
4. & circumference & $2.82^{\mathrm{a}} \pm 0.30$ & $7.70^{\mathrm{b}} \pm 0.55$ & $11.67 \mathrm{c} \pm 0.80$ & $18.27^{\mathrm{d}} \pm 0.64$ \\
& & $(2-4)$ & $(6-9.2)$ & $(10-15)$ & $(16.00-20.00)$ \\
\hline
\end{tabular}

Table II. Correlation coefficient between age of foetus, weight of foetus and various biometrical parameters of pelvic urethra of prenatal goat in Group- II. III, IV and V.

\begin{tabular}{|c|c|c|c|c|c|c|}
\hline & $\begin{array}{l}\text { Age of } \\
\text { foetus }\end{array}$ & $\begin{array}{l}\text { Weight of } \\
\text { foetus }\end{array}$ & Length & Height & Width & Circumference \\
\hline \multicolumn{7}{|c|}{ Group-II } \\
\hline Age of foetus & 1.000 & $0.984^{* *}$ & $0.966^{* *}$ & $0.963^{* *}$ & $0.978^{*}$ & $0.945^{*^{*}}$ \\
\hline Weight of foetus & $0.984^{*}$ & 1.000 & $0.971^{* *}$ & $0.991^{* *}$ & $0.996^{*}$ & $0.983^{*}$ \\
\hline Length & $0.966^{*}$ & $0.971^{* *}$ & 1.000 & $0.980^{* *}$ & $0.975^{*}$ & $0.975^{*^{*}}$ \\
\hline Height & $0.963^{*}$ & $0.991^{* *}$ & $0.980^{* *}$ & 1.000 & $0.997 *^{*}$ & $0.991 *^{*}$ \\
\hline Width & $0.978^{*}$ & $0.996^{* *}$ & $0.975^{* *}$ & $0.997^{* *}$ & 1.000 & $0.982 *^{*}$ \\
\hline Circumference & $0.945^{*}$ & $0.983^{* *}$ & $0.975^{* *}$ & $0.991^{* *}$ & $0.982^{*}$ & 1.000 \\
\hline \multicolumn{7}{|c|}{ Group-III } \\
\hline Age of foetus & 1.000 & $0.996 * *$ & $0.982 * *$ & $0.995^{* *}$ & $0.996^{* *}$ & $0.928 * *$ \\
\hline Weight of foetus & $0.996 * *$ & 1.000 & $0.972 * *$ & $0.995 * *$ & $0.985^{* *}$ & $0.899 *$ \\
\hline Length & $0.982 * *$ & $0.972 * *$ & 1.000 & $0.979 * *$ & $0.984 * *$ & $0.967 * *$ \\
\hline Height & $0.995 * *$ & $0.995 * *$ & $0.979 *$ & 1.000 & $0.991 * *$ & $0.916^{*}$ \\
\hline Width & $0.996 * *$ & $0.985 * *$ & $0.984 * *$ & $0.991^{* *}$ & 1.000 & $0.948 * *$ \\
\hline Circumference & $0.928 * *$ & $0.899 *$ & $0.967 * *$ & $0.916^{*}$ & $0.948 * *$ & 1.000 \\
\hline \multicolumn{7}{|c|}{ Group-IV } \\
\hline Age of foetus & 1.000 & $0.998 * *$ & $0.985 * *$ & $0.992 * *$ & $0.959 * *$ & $0.978 * *$ \\
\hline Weight of foetus & $0.998 * *$ & 1.000 & $0.993 * *$ & $0.992 * *$ & $0.955^{* *}$ & $0.981 * *$ \\
\hline Length & $0.985^{* *}$ & $0.993 * *$ & 1.000 & $0.992 * *$ & $0.964 * *$ & $0.993 * *$ \\
\hline Height & $0.992 * *$ & $0.992 * *$ & $0.992 * *$ & 1.000 & $0.984 * *$ & $0.994 * *$ \\
\hline Width & $0.959 * *$ & $0.955 * *$ & $0.964 * *$ & $0.984 * *$ & 1.000 & $0.987 * *$ \\
\hline Circumference & $0.978 * *$ & $0.981 * *$ & $0.993 * *$ & $0.994 * *$ & $0.987 * *$ & 1.000 \\
\hline \multicolumn{7}{|c|}{ Group-V } \\
\hline Age of foetus & 1.000 & $0.995 * *$ & $0.945 * *$ & $0.905^{*}$ & $0.913^{*}$ & $0.988 * *$ \\
\hline Weight of foetus & $0.995^{* *}$ & 1.000 & $0.974 * *$ & $0.943 * *$ & $0.949 * *$ & $0.994 * *$ \\
\hline Length & $0.945^{* *}$ & $0.974 * *$ & 1.000 & $0.992 * *$ & $0.993 * *$ & $0.973 * *$ \\
\hline Height & $0.905^{*}$ & $0.943 * *$ & $0.992 * *$ & 1.000 & $0.996 * *$ & $0.951 * *$ \\
\hline Width & $0.913^{*}$ & $0.949 * *$ & $0.993 * *$ & $0.996^{* *}$ & 1.000 & $0.948 * *$ \\
\hline Circumference & $0.988 * *$ & $0.994 * *$ & $0.973 * *$ & $0.951 * *$ & $0.948 * *$ & 1.000 \\
\hline
\end{tabular}

** Correlation is significant at the 0.01 level (2-tailed).

* Correlation is significant at the 0.05 level (2-tailed) 


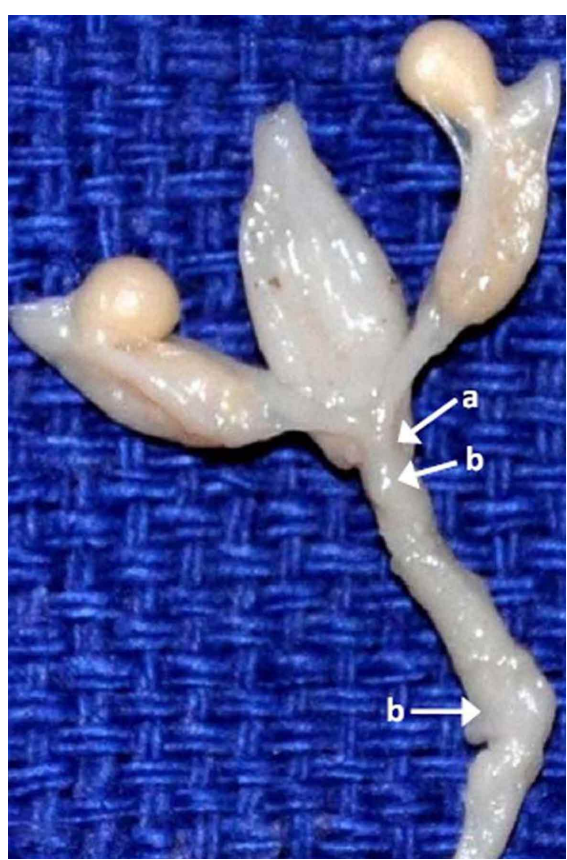

Fig. 1. Photograph of pelvic urethra of 55 days old goat foetus showing vas deferens (a) swellings of vesicular glands (b) and bulbourethral glands (c).

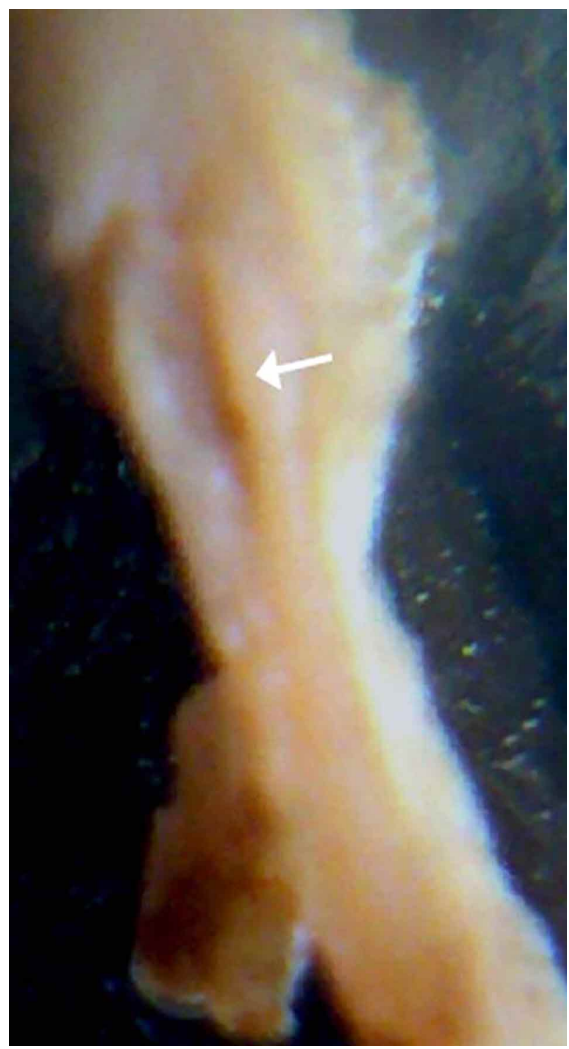

Fig. 2. Photograph of dissected pelvic urethra of 75 days old goat foetus showing colliculus seminalis (arrow). was highly significantly correlated with height (0.992), width (0.964) and circumference (0.993). Similarly other parameters were also highly significantly correlated with each other.

In group $\mathrm{V}$, the fat layer around the vesicular gland became very thick and encircled whole vesicular glands. With the advancement in the age of gestation, the wall of pelvic urethra became more muscular than previous age animals. The thickness of collicullus seminalis increased (Fig. 4). The opening of ducts of vesicular glands was also seen on either side of collicullus seminalis on 145 days of gestation. Farooqui observed the opening of vas deferens and vesicular glands on either side of collicullus seminalis at 125 days of gestation. The pars disseminata of prostate was also seen on the internal surface of pelvic urethra. All the parameters i.e. length, Height, Width and circumference increased with the advancement in the gestation period. In group $\mathrm{V}$, the overall mean length, height, width and circumference were $27.20 \pm 1.40$, $4.43 \pm 0.16, \quad 4.42 \pm 0.17$ and $18.27 \pm 0.64 \mathrm{mms}$, respectively. Statistical analysis of data revealed that, the length, height, width and circumference of pelvic urethra increased with the increase in gestation period (Table I).

Maximum growth was observed in the circumference and length of pelvic urethra The length and circumference of pelvic urethra increased approximately 7 and 9 times from group II to group V (Table I). The Height was slightly higher than Width up to group IV. But in

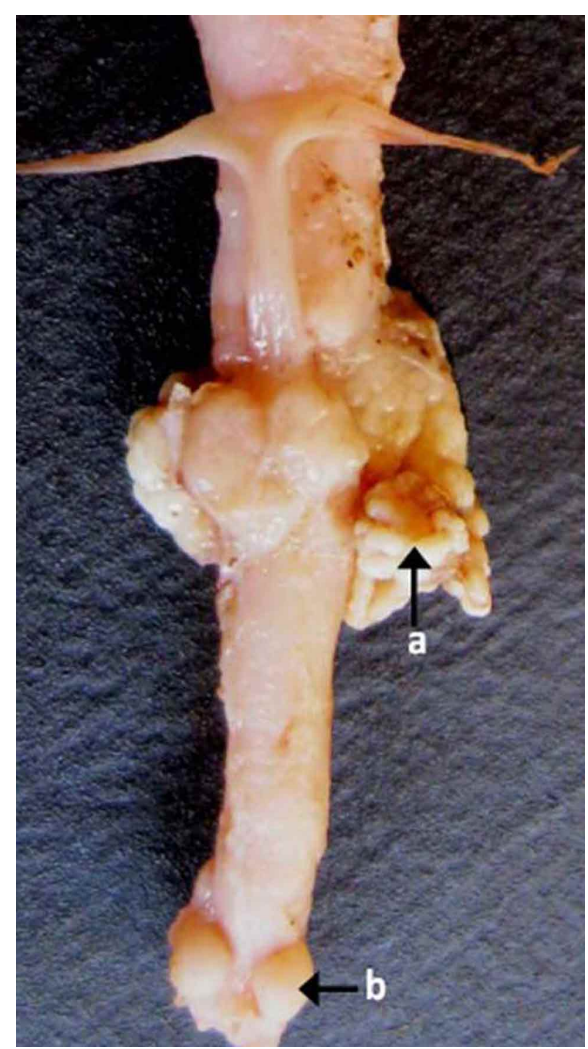

Fig. 3. Photograph of pelvic urethra of 93 days old goat foetus showing fat deposition in the cranial part of pelvic urethra and around the vesicular gland (a) and bulbourethral gland (b).

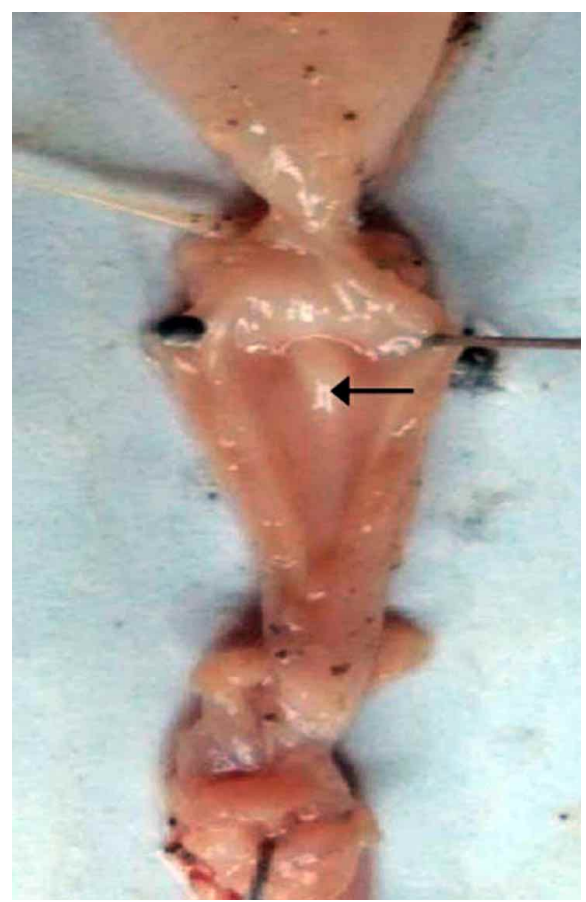

Fig. 4. Photograph of pelvic urethra of 145 days old goat foetus showing collicullus seminalis (arrow). 
group $\mathrm{V}$ the height and width were almost same, indicated that the pelvic urethra was almost rounded in shape.

In group $\mathrm{V}$ the length and circumference of pelvic urethra was highly significantly correlated with age of foetus at $1 \%$ level of significance. The Height and Width were significantly correlated with age of foetus at $5 \%$ level of significance. The weight of foetus was highly significantly correlated with length (0.974), height (0.943), width (0.949) and circumference (0.994) at $1 \%$ level of significance. The length of pelvic urethra was highly significantly correlated with height (0.992), width (0.993) and circumference (0.973) of pelvic urethra and vice versa. The circumference of pelvic urethra was also highly significantly correlated with height (0.951) and width (0.948) at $1 \%$ level of significance. Overall analysis of data showed that, the length, height, width and circumference of pelvic urethra increased significantly throughout the gestation period. The length, height, width and circumference were highly significantly correlated with each other throughout the gestation period. Analysis of data revealed that, growth of pelvic urethra was fastest in group $\mathrm{V}$ followed by group IV and group III.

Histology. In group I (0-30 days) at 28 days of gestation, within the mass of mesenchymal cells a, cluster of cells was seen. In this cluster of cells a cleft was observed referred as the future urogenital sinus (Fig. 5). The peripheral cells of the differentiating sinus were cuboidal type. This cleft was continuous behind with the developing urethral plate. Patten (1948) stated that urogenital sinus remained narrow in pig embryo and gave rise to urethra. Noden \& de Lahunta (1985) described that, in mammalian embryo, the urogenital sinus divided into pelvic and phallic region. The caudal part of pelvic region of urogenital sinus was developed into urethra, whereas its cranial part developed into urinary bladder. The same was observed by McGeady et al. (2006). The cytoplasm of peripheral epithelial cells was lightly eosinophilic. $\mathrm{Nu}-$ clear membrane was distinct, one or two nucleoli were clearly distinguishable. The other cells just beneath the peripheral layer also show same tinctorial characteristics feature. The cells surrounding sinus were arranged in chord like fashion.

In group II, at 55 days of gestation, the various layer of pelvic urethra were not distinct however the process of luminization started in pelvic urethra (Figs. 6-8). In the cranial part of pelvic urethra the process of luminization started by the process of cell degeneration (Fig. 6). As we move towards the caudal part of urethra, the size of lumen increased. In the mid part of pelvic urethra, a narrow lumen was seen along with the process of cell degeneration (Fig. 7), but in the caudal part a well developed lumen was formed in the pelvic urethra (Fig. 8). At 57 days of gestation, all four layers were distinct as tunica mucosa, submucosa, tunica

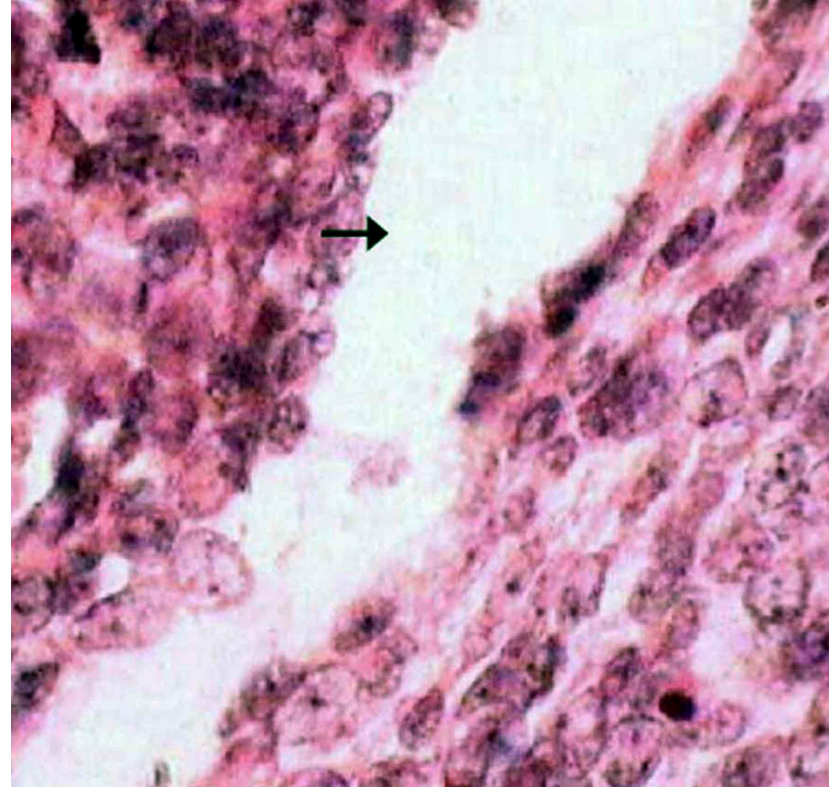

Fig. 5. Photomicrograph of 28 days old goat embryo showing urogenital sinus (arrow) H \& E X1000.

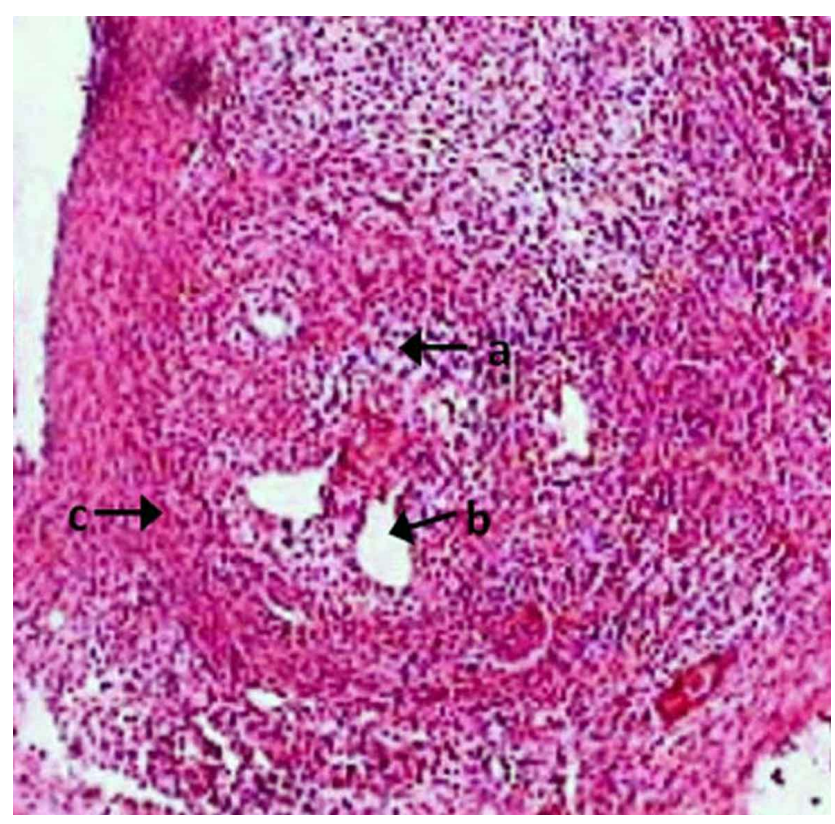

Fig. 6. Photomicrograph of cranial part of pelvic urethra of 55 days old goat foetus showing differentiating urethral lumen (a), ducts of vas deferens (b) and urethral muscles (c). H \& E X100.

muscularis and tunica adventitia (Fig. 9). In contrast to this Farooqui described four distinct layers in the pelvic urethra of prenatal goat at 43 days of gestation. The lumen was star shaped. The folding of mucosa took place having indistinct lamina epithelialis. The same was reported by Farooqui at 53 days of gestation. The lumen was star shaped. The average height of epithelium was $245.34 \pm 9.32 \mu \mathrm{m}$. The submucosa 


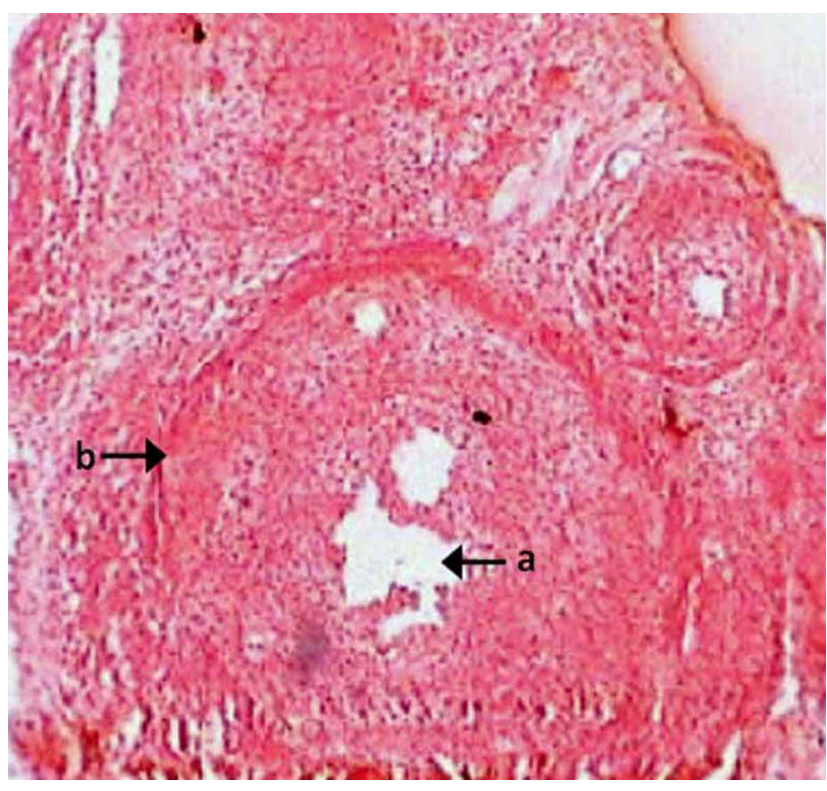

Fig. 7. Photomicrograph of middle part of pelvic urethra of 55 days old goat foetus showing urethral lumen (a) and urethral muscles (b). H \& E X100.

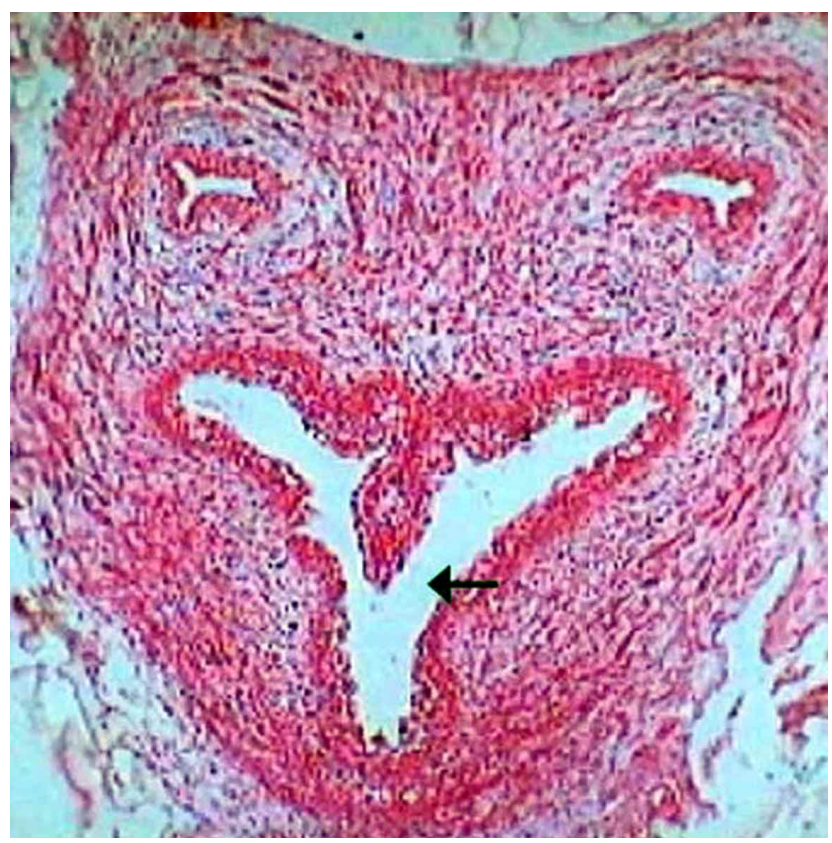

Fig. 8. Photomicrograph of caudal part of pelvic urethra of 55 days old goat foetus showing urethral lumen(arrow). H \& E X100.

showed some aggregation of cells for the formation of future prostate gland. The lamina propria submucosa consisted of densely populated mesenchymal cells, small capillaries and differentiating fibroblasts. The average thickness of lamina propria- submucosa was $1001 \pm 45.2 \mu \mathrm{m}$. The muscular layer was composed of circularly arranged smooth muscle cells. These were arranged around the submucosa and were darkly

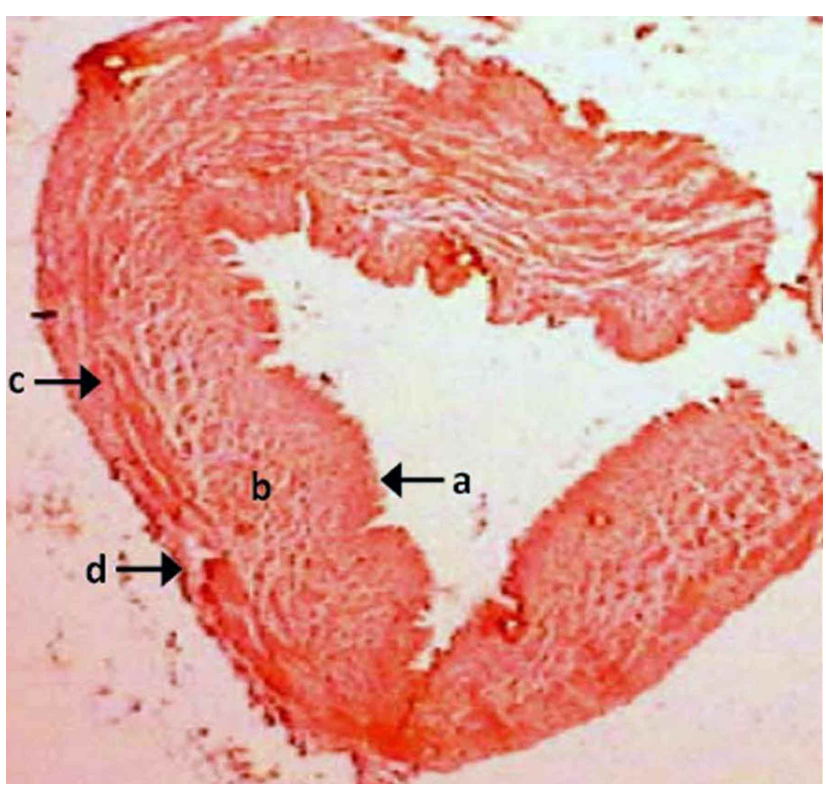

Fig. 9. Photomicrograph of pelvic urethra of 57 days old goat foetus showing the tunica mucosa (a), submucosa (b), tunica muscularis (c) and tunica adventitia (d). H \& E X100.

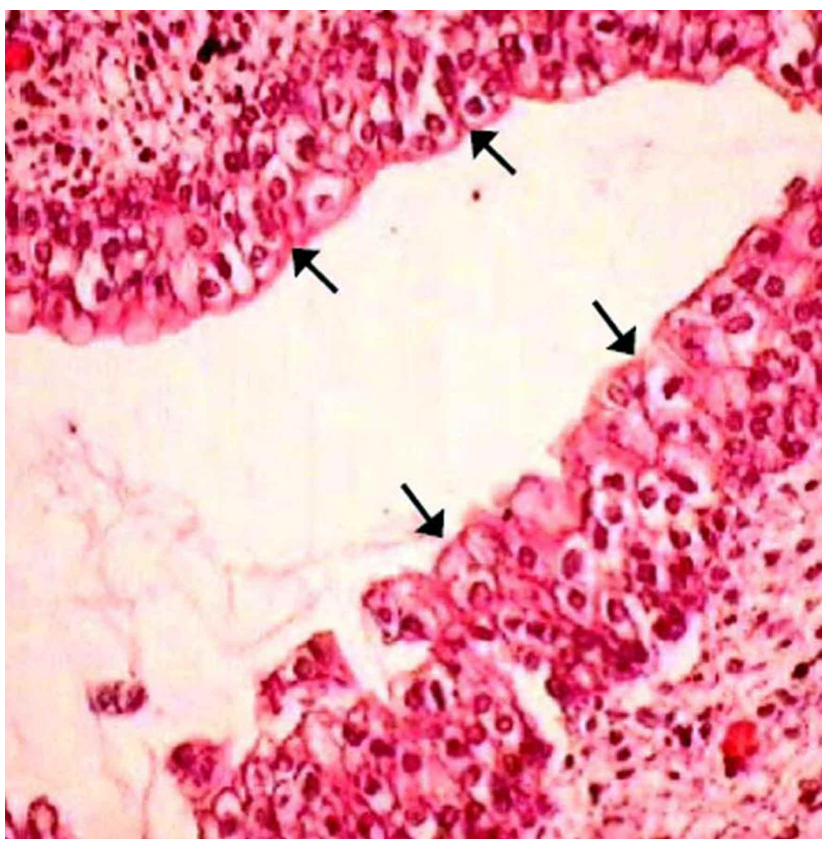

Fig. 10. Photomicrograph of pelvic urethra of 81days old goat foetus showing transitional epithelium, lining the lumen of urethra (arrow). Masson's trichome stain X400.

stained than the submucosa. The average thickness of muscular layer was $897.57 \pm 100 \mu \mathrm{m}$. The tunica adventitia consisted of loose connective tissue, mesenchymal cells and blood capillaries. Its average thickness was $100.37 \pm 24.5 \mu \mathrm{m}$. At 59 days of gestation, the urethral epithelium was in the process of its formation, showed mostly polyhedral type of cells. The epithelium was stratified showing 4-5 layers of 


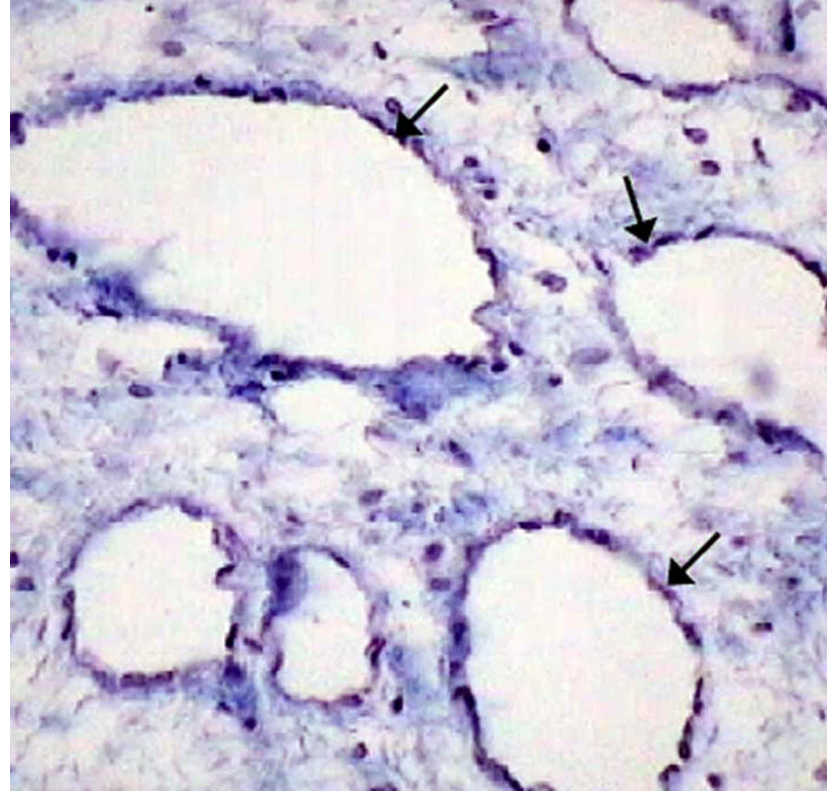

Fig. 11. Photomicrograph of pelvic urethra of 150 days old goat foetus showing collagen fibres around cavernous space (arrow). Masson's trichome stain X400.

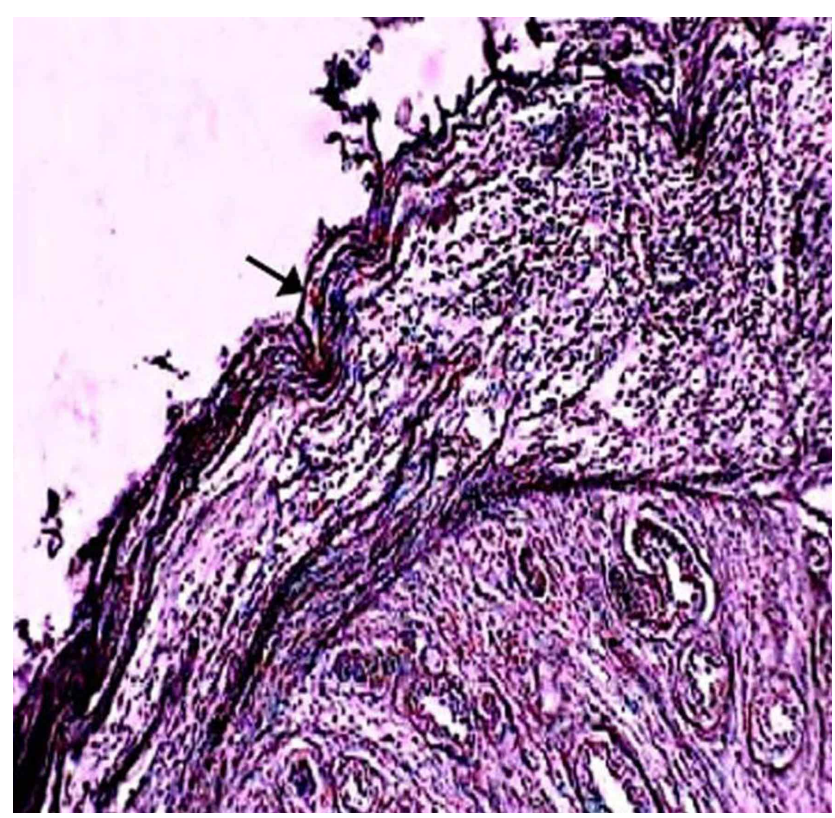

Fig. 12. Photomicrograph of pelvic urethra of 116 days old goat foetus showing reticular fibres in tunica adventitia (arrow). Wilder's reticular stain X100.

cells. The basement membrane was not distinct. The average height of epithelium became $230.21 \pm 7.32 \mu \mathrm{m}$. The nuclei of epithelial cells were large and mostly rounded in shape. The cavernous spaces were observed in submucosa. The nerve bundle was also seen in the tunica adventitia. The average thickness of the lamina propria-submucosa, tunica

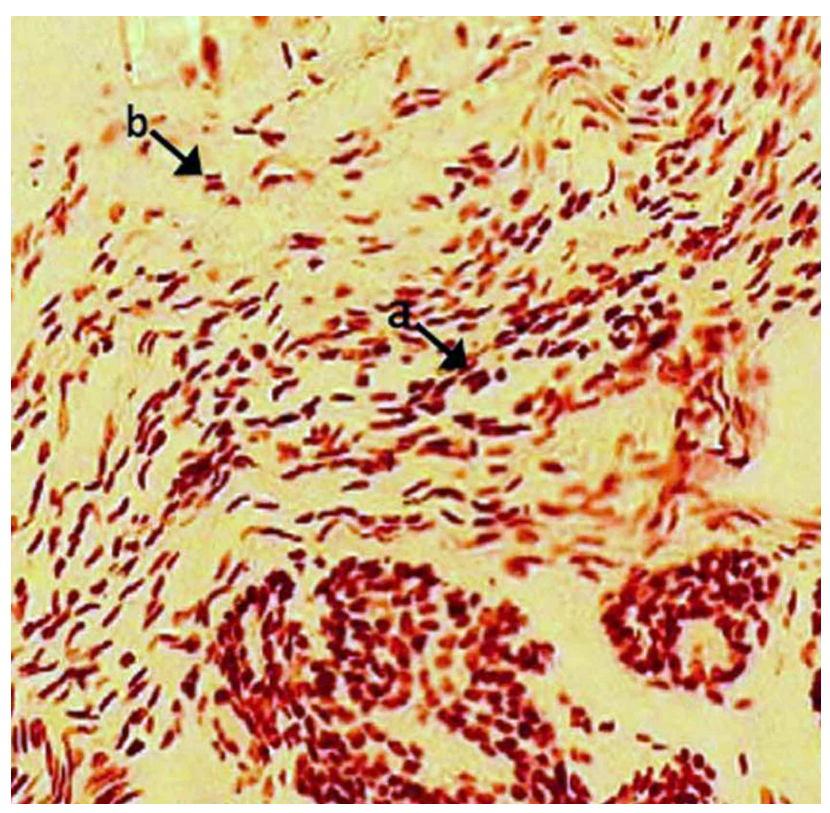

Fig. 13. Photomicrograph of pelvic urethra of 145 days old goat foetus showing intense Feulgen's reaction in the nuclei of muscle cells (a) and moderate reaction in connective tissue cells of tunica adventitia (b) Feulgen's reaction X400.

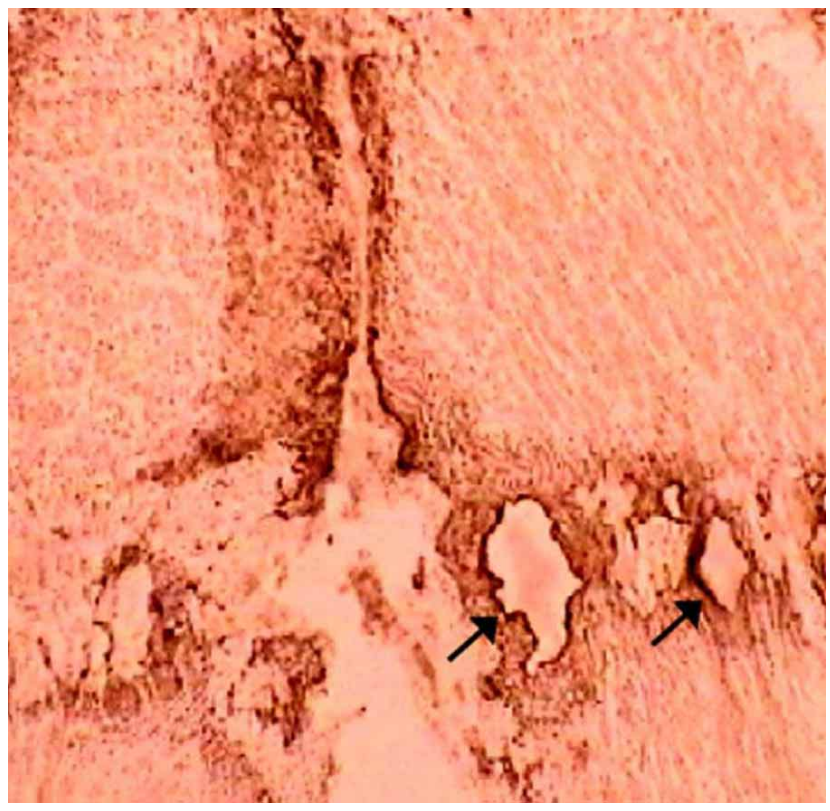

Fig. 14. Photomicrograph of pelvic urethra 100 days old goat foetus showing intese alkaline phosphatase reaction around cavernous spaces (arrow). Gomori (modified) stain X 100.

muscularis and tunica adventitia was $1045 \pm 35.4$, $900.45 \pm 107.2$ and $112.34 \pm 27.5 \mu \mathrm{m}$, respectively.

In group II the overall average height of epithelium was $234.97 \pm 11.2 \mu \mathrm{m}$. The average thickness of lamina propria- submucosa, tunica muscularis and tunica adventitia 
were $976.91 \pm 95.18,415.51 \pm 12.23,208.84 \pm 32.39 \mu \mathrm{m}$, respectively (Table-).

In group III, at 70 days of gestation, urethral lumen was lined by distinct transitional epithelium whereas Farooqui reported the presence of distinct transitional epithelium in the pelvic urethra at 53rd days of gestation in goat foetus. The average height of epithelium became $222.01 \pm 8.4 \mu \mathrm{m}$. In the submucosa the cavernous spaces were more than the previous age group. Thin collagen fibres appeared in the submucosa. The average thickness of lamina propria submucosa was $1192.35 \pm 59.2 \mu \mathrm{m}$. The tunica muscularis was thicker at ventrolateral aspect of urethra. The average thickness of muscular layer and tunica adventitia was $1070 \pm 109$ and $289.37 \pm 25.2 \mu \mathrm{m}$, respectively. At 81 days of gestation, the mucosa was composed of transitional epithelium and lamina propia (Fig. 10). The submucosa contained loosely arranged mesenchymal cells and lots of cavernous spaces. The average thickness of lamina propia submucosa, muscular layer and tunica adventitia was 1944.08 $\pm 135.11,1491.8 \pm 45.63$ and $365.02 \pm 52.38 \mu \mathrm{m}$, respectively. At 85 days of gestation, the urethral lumen became wider than earlier age group. The thickness of different layers increased with increased in gestation period but the height of epithelium decreased.

In group III the overall average height of epithelium was $215.4 \pm 10.52 \mu \mathrm{m}$. The average thickness of lamina propia submucosa, tunica muscularis and tunica adventitia were $1370.83 \pm 191.01,1070.57 \pm 109.01,249.31 \pm 26.91 \mu \mathrm{m}$, respectively (Table III).

In group IV, the lumen became typical star shaped, lined by transitional epithelium. At 93 days of gestation the height of epithelium was $135.36 \pm 8.01 \mu \mathrm{m}$. The average thickness of lamina propria submucosa, tunica muscularis and tunica adventitia was 2026.92 $\pm 209.82,1558.52 \pm 54.62$, and $463.44 \pm 28.81 \mu \mathrm{m}$, respectively.

At 116 days of gestation a distinct capsule of prostate gland was present between submucosa and tunica muscularis of urethra. The capsule was described in prostate gland by Archana (2006) in one day old Gaddi goat. In submucosa the pars disseminata of prostate gland was present all around the urethral lumen. In tunica muscularis, muscles fibres became more compact than previous age group. The thickness of tunica adventitia increased with increased in gestation period. Very fine to thick collagen and reticular fibres were present in submucosa, around muscles and in tunica adventitia. Very few fine elastic fibres were also present in the tunica adventitia. The height of epithelim was $125.36 \pm 10.38 \mu \mathrm{m}$. The average thickness of lamina propriasubmucosa, tunica muscularis and tunica adventitia were
$2369.96 \pm 36.15,2663.26 \pm 77.23$, and $281.0 \pm 11.91 \mu \mathrm{m}$, respectively.

In group IV the overall height of epithelium was $130.36 \pm 6.40 \mu \mathrm{m}$. The average thickness of lamina proria submucosa, tunica muscularis and tunica adventitia was $2198.44 \pm 115.51,1611.02 \pm 353.65$ and $372.22 \pm 33.77 \mu \mathrm{m}$, respectively (Table III).

In group $\mathrm{V}$, at 140 days of gestation the transitional epithelium was thrown into numerous folds as observed by Farooqui. The average height of epithelium was $120.01 \pm 8.4$ $\mu \mathrm{m}$. In lamina propria- submucosa, cavernous spaces were irregular in shape. Very fine elastic fibres were seen in the lamina propria-submucosa and in the wall of blood vessels. These were more numerous between the urethral epithelium and glandular tissue of pars disseminata as compared to previous groups. The muscular layer increased in thickness. The striated muscles fibres became more compact and were arranged circularly. The tunica adventitia contained loose connective tissue, mesenchymal cells, blood capillaries and developing nerve fibres. The average thickness of lamina propria submucosa, tunica muscularis and tunica adventitia was $2369.96 \pm 36.15,2663.26 \pm 77.23$, and $281.0 \pm 11.91 \mu \mathrm{m}$, respectively. With the increased in gestation period the height of epithelium as well as the thickness of various layers also increased.

At 150 collagen and reticular fibres were present around cavernous spaces (Fig. 11), which became more distinct with the increased in gestation period. Very fine elastic fibres were also present in the submucosa and in the wall of blood vessels.

In group $\mathrm{V}$ the overall average height of epithelium was $130.36 \pm 6.40 \mu \mathrm{m}$. The average thickness of lamina propria submucosa, tunica muscularis and tunica adventitia was $4150.21 \pm 125.24,3103.33 \pm 157.08$ and $604.69 \pm 38.08$ $\mu \mathrm{m}$, respectively (Table III). All micrometrical parameters of pelvic urethra increased with increase in gestation period except height of epithelium.

Histochemistry. In group II (31-60 days of gestation), the cytoplasm of epithelial cells lining the lumen of urethra showed mild reaction for PAS and negative reaction for acid mucopolysaccharides. As the gestation period advanced, the reaction for acid mucopolysaccharides became mild. The PAS reaction remained mild in III and IV group. But in group V (121 -150 days of gestation), the cytoplasm of epithelial cells showed intense reaction for PAS and acid mucopolysaccharides. Farooqui also reported mild to moderate activity in the basal layer and intense reaction for AMPs in the superficial cells of transitional epithelium in 
Table III. Micrometrical parameters of pelvic urethra in prenatal goat in various gestation period.

\begin{tabular}{clcccc}
\hline S.N. & Parameters $($ in $\mu \mathrm{m})$ & $\begin{array}{c}\text { Group II } \\
\text { Mean } \pm \text { S.E. }\end{array}$ & $\begin{array}{c}\text { Group III } \\
\text { Mean } \pm \text { S.E. }\end{array}$ & Group IV Mean \pm S.E. & Group V Mean \pm S.E. \\
\hline 1. & Epithelium & $234.97 \pm 11.2$ & $215.4 \pm 10.52$ & $139.2 \pm 6.40$ & $130.36 \pm 6.90$ \\
& & $(143.2-270)$ & $(150.3-269.3)$ & $(106-169.1)$ & $(95-159.3)$ \\
2. & Lamina propria- & $976.91 \pm 95.18$ & $1370.83 \pm 191.01$ & $2198.44 \pm 115.51$ & $4150.21 \pm 125.24$ \\
& submucosa & $(581.8-1275)$ & $(126.5-2207.1)$ & $(1538-2583)$ & $(3923.2-4794.3)$ \\
& & $415.51 \pm 12.23$ & $1070.57 \pm 109.01$ & $1611.02 \pm 353.65$ & $3103.33 \pm 157.08$ \\
3. & Tunica muscularis & $(345.3-459.7)$ & $(105-1305.2)$ & $(465.2-2889.4)$ & $604.69 \pm 38.08$ \\
& & $208.84 \pm 32.39$ & $240.31 \pm 126.91$ & $372.22 \pm 33.77$ & $(479.9-900)$ \\
4. & Tunica adventitia & $(25-362.2)$ & $(274.2-323.3)$ & $(245.2-315.5)$ & \\
& & & & & \\
\hline
\end{tabular}

pelvic urethra of goat. He further reported mild to intense reaction for PAS in various layers of transitional epithelium. The connective tissue of lamina propria submucosa showed mild reaction for PAS and intense reaction for acid mucopolysaccharides in group II. The intense acid mucopolysaccharides reaction continued up to group $\mathrm{V}$ during prenatal life. With the advancement in the age PAS reaction became intense in the lamina propria submucosa. Similar trend of PAS and AMPs reaction in lamina propria submucosa of pelvic urethra was described by Farooqui. However he has reported mild to moderate PAS and AMPs reaction during the last trimester of pregnancy. The endothelium of cavernous spaces showed mild reaction for PAS and negative reaction for AMPs In group II. With the advancement in the age, both the reaction became mild to moderate in group $\mathrm{V}$. The nuclei of the cells of lamina propria submucosa (mesenchymal cells) showed mild to moderate reaction for DNA in group II. In group IV and V the nuclei of epithelial cells showed moderate reaction for DNA (Fig. 13). The same reactions were seen in the nuclei of cells of tunica muscularis. The increase in the intensity of Feulgen reaction with the advancement in age was due to the increase in growth and proliferation of cells. In group II the tunica muscularis and tunica adventitia showed mild to negative reaction for PAS and mild reaction for AMPs. The reaction became intense for PAS and moderate for AMPs. Intense alkaline phosphatase reaction was seen in the wall of cavernous spaces and the blood vessels (Fig. 14)

VREMA, A.; ARCHANA, A.; FAROOQUI, M. M. \& PRAKASH, A. Desarrollo prenatal de la uretra pélvica en cabras (Capra hircus). Int. J. Morphol., 31(2):729-738, 2013.

RESUMEN: El estudio se realizó sobre embriones/fetos de cabras de 0 a 150 días de gestación, divididos en grupo I (030 días), grupo II (31-60 días), el grupo III (61-90 días), grupo IV (91 a 120 días) y grupo V (121-150 días de gestación). En el grupo I embriones enteros fueron procesados mediante cortes seriados, en el resto de los grupos, la uretra pélvica fue disecada y los tejidos de las áreas representativas se utilizaron para su estudio. Macroscópicamente, a los 49,33 días de gestación de la uretra pélvica estaba presente en forma de tubo cilíndrico liso, aproximadamente $4 \mathrm{~mm}$ de longitud. El primordio de la glándula vesicular y la glándula bulbouretral apareció a los 52 días de gestación en el cruce de cuello de la vejiga urinaria con la uretra pélvica y el cruce de la uretra pélvica y pene respectivamente. La longitud, ancho, alto y circunferencia de la uretra pélvica aumentó con el avance del período de gestación, sin embargo, la longitud ( 7 veces) y el perímetro (9 veces) aumentó en el grupo II y V. Los parámetros morfométricos (longitud, ancho, alto y circunferencia) de la uretra pélvica se correlacionaron significativamente con la edad y el peso del feto durante toda la gestación. El colículo seminal, que estaba presente en la forma de cresta a los 72 días de gestación, se mostró distinta a los 75 días de gestación. Histológicamente, en 28 días de gestación, el seno urogenital estaba presente como una hendidura con un grupo de células. En 55 días de gestación, el proceso de luminización comenzó en la pared de la uretra pélvica, que comenzó en su primera parte caudal y procedió cranealmente. Las cuatro capas (túnica mucosa, submucosa, muscular y adventicia) eran distintas. La luz estaba cubierta con 3-4 capas de epitelio estratificado en el grupo II, pero en el grupo III a los 70 días de gestación y más, un epitelio de transición distinto estuvo presente. La formación de espacios cavernosos comenzó a los 59 días de gestación. Su número y tamaño aumentan con el aumento en el período de gestación. El espesor de la submucosa, muscular y adventicia aumenta con el avance de la edad del feto, mientras que la altura del epitelio disminuye.

PALABRAS CLAVE: Anatomía; Histología; Uretra pélvica; Cabra. 


\section{REFERENCES}

Archana. Correlative anatomy of the testis and accessory sex glands of Gaddi goat (Capra hircus). Ph.D Thesis, Mathura, Pt. Deen Dayal Pashu Chikitsa Vigyan Vishwavidyalaya Evam Go Anusandhan Sansthan, Mathura (U. P.), 2006.

Bancroft, J. D. \& Stevens, A. Theory and practice of histological techniques. Edinburgh, London, New York, Churchill Livingstone, 1977.

Davenport, H. A. Histological and histochemical technics. Philadelphia, W. B. Saunders Company, 1960.

Evans, H. E. \& Sack, W. O. Prenatal development of domestic and laboratory mammals: growth curves, external features and selected references. Zentralbl. Veterinarmed. C, 2(1):11-45, 1973.

Farooqui, M. M. Morphological, Histological and Histochemical studies on male genital system of goat (Capra hircus). Ph.D Thesis, Kanpur, CSA University, 2004.

Luna, L. G. Routine staining procedures. Hematoxylin and eosin stains. Manual of histologic staining methods of the Armed Forces Institute of Pathology. $3^{\text {rd }}$ ed. New York, McGraw-Hill, 1968. pp.32-39.

McGeady, T. A.; Quinn, P. J.; FitzPatrick, E. S. \& Ryan, M. T. Veterinary Embryology. Oxford, Blackwell Publishing Ltd, 2006.

Noden, D. M. \& de Lahunta, A. The Embryology of Domestic animals. Baltimore, Williams and Wilkins Company, 1985. pp.332-40.

Patten, B. M. Embryology of the Pig. New York, McGraw-Hill Book Co., 1948. p.211.

Snedecor, G. W. \& Cochran, W. G. Statistical methods. 6th ed. Calcutta, India, Oxford and IBH Publishing Co., 1967.

Singh, Y.; Sharma, D. N. \& Dhingra, L. D. Morphogenesis of the testis in goat. Indian J. Anim. Sci., 49:925-31, 1979.

\author{
Correspondence to: \\ Dr. Archana Pathak \\ Associate Professor \\ Dept. of Anatomy \\ College of Veterinary Science and Animal Husbandry \\ DUVASU- Mathura (U.P) \\ INDIA
}

Email: pathak_arcvik@yahoo.com

Received: 10-09-2012

Accepted: 22-03-3013 